\title{
Evaluation of 2,4-D Amine, Glyphosate, 2,4-D Amine plus Glyphosate DMA and 2,4-D Choline/Glyphosate DMA for Their Efficacy on Glyphosate Susceptible and Resistant Canada Fleabane Populations
}

\author{
Laura Ford1, Nader Soltani1 ${ }^{*}$, Darren E. Robinson', Robert E. Nurse ${ }^{2}$, Allan McFadden ${ }^{3}$, \\ Peter H. Sikkema ${ }^{1}$ \\ ${ }^{1}$ University of Guelph Ridgetown Campus, Ridgetown, Canada \\ ${ }^{2}$ Agriculture and Agri-Food Canada, Harrow, Canada \\ ${ }^{3}$ Dow Agrosciences, Guelph, Canada \\ Email: soltanin@uoguelph.ca
}

Received 18 July 2014; revised 23 August 2014; accepted 22 September 2014

Copyright (C) 2014 by authors and Scientific Research Publishing Inc.

This work is licensed under the Creative Commons Attribution International License (CC BY). http://creativecommons.org/licenses/by/4.0/

(c) (i) Open Access

\section{Abstract}

The 2,4-D choline/glyphosate DMA formulation has reduced drift and volatility compared to the amine or ester formulation of 2,4-D and therefore is advantageous compared to a tank mix of 2,4-D amine or ester with glyphosate. The objective of this research was to compare the control of glyphosate susceptible and glyphosate resistant Canada fleabane with 2,4-D choline/glyphosate DMA with 2,4-D amine, glyphosate, and a tank mix of 2,4-D amine and glyphosate. Ten rates of 2,4-D amine ( 0 - $\left.6708 \mathrm{~g} \cdot \mathrm{ae} \cdot \mathrm{ha}^{-1}\right)$, glyphosate $\left(0\right.$ - $\left.7052 \mathrm{~g} \cdot \mathrm{ae} \cdot \mathrm{ha}^{-1}\right)$, a tank mix of glyphosate plus $2,4-$ D amine ( 0 - $7052 \mathrm{~g} \cdot \mathrm{ae} \cdot \mathrm{ha}^{-1}+0$ - 6708), and 2,4-D choline/glyphosate DMA (0 - $\left.13760 \mathrm{~g} \cdot \mathrm{ae} \cdot \mathrm{ha} \mathrm{a}^{-1}\right)$ were examined in the greenhouse for the control of two susceptible (GS) and two resistant to glyphosate (GR) Canada fleabane biotypes. The tank mix of 2,4-D amine plus glyphosate and 2,4-D choline/glyphosate DMA provided equivalent control of the GR Canada fleabane biotypes at 35 days after the application (DAA). The 2,4-D choline/glyphosate DMA treatment was more efficacious than the tank mix on the GS biotypes. Glyphosate $\left(880 \mathrm{~g} \cdot \mathrm{ae} \cdot \mathrm{ha}^{-1}\right)$ provided $50 \%$ and $100 \%$ control of the resistant and susceptible biotypes, respectively. The 2,4-D choline/glyphosate DMA formulation and the tankmix of 2,4-D amine and glyphosate provided similar control of GR Canada fleabane.

\footnotetext{
${ }^{*}$ Corresponding author.

How to cite this paper: Ford, L., Soltani, N., Robinson, D.E., Nurse, R.E., McFadden, A. and Sikkema, P.H. (2014) Evaluation of 2,4-D Amine, Glyphosate, 2,4-D Amine plus Glyphosate DMA and 2,4-D Choline/Glyphosate DMA for Their Efficacy on Glyphosate Susceptible and Resistant Canada Fleabane Populations. Agricultural Sciences, 5, 1053-1060. 
Keywords

Enlist, Glyphosate Resistant, Height, Injury, Seed Moisture, Yield

\section{Introduction}

Canada fleabane (Conyza canadensis (L.) Cronquist) is native to North America and has spread to many parts of the world including Europe, Australia and parts of Africa [1]. It is typically found in coarse textured, undisturbed soil [2] [3]. Eliminating tillage has created an ideal growing condition for this plant, as the germination success of Canada fleabane is greatest when the seed is in the top $1 \mathrm{~cm}$ of the soil [4]. Canada fleabane is mostly self-pollinated with a small portion (4\%) cross pollinating [4]. The spread of this weed has been due to its large seed production (up to 1 million seeds/plant) and the slow settlement velocity $\left(0.323 \mathrm{~m} \cdot \mathrm{sec}^{-1}\right)$ which allows it to be wind dispersed up to $500 \mathrm{~km}$ [2] [5]. Canada fleabane is extremely competitive with crops, reducing soybean yield up to $90 \%$ [6]. Controlling this weed is important to reduce the risk of yield loss.

Canada fleabane is currently resistant to five herbicide groups, including the Group 2 (acetolactase synthase (ALS) inhibitors), Group 5 (photosystem II inhibitors), Group 7 (ureas), Group 9 (glycines) and Group 22 (bipyridiliums) [7]. Some biotypes of Canada fleabane are multiple resistant to two or more of these herbicide groups [7]. In Canada in 2012, there were 19 sites that were confirmed multiple resistance to Group 2 and 9 herbicides [8]. Canada fleabane can rapidly develop resistance to herbicides and therefore multiple modes of action should be used to control this weed. Beckie and Rebound [9] have shown that herbicide mixtures are very effective at delaying herbicide resistance. Mixtures of glyphosate (840 g.ae $\left.\cdot \mathrm{ha}^{-1}\right)$ and 2,4-D amine (280 g.ae $\left.\cdot \mathrm{ha}^{-1}\right)$ provided greater than $97 \%$ control of Canada fleabane [2]. 2,4-D ester (560 g.ae $\cdot \mathrm{ha}^{-1}$ ) applied alone provided 97\% control of Canada fleabane, and as of now Canada fleabane has not been found to be resistant to 2,4-D [6] [7].

A premix formulation of 2,4-D choline and glyphosate dimethylamine (DMA) has been developed. The 2,4-D choline is a new salt of 2,4-D, this combined with the formulation science and manufacturing processes of the company has resulted in 96\% and 88\% less volatile than 2,4-D ester and 2,4-D dimethylamine, respectively [10]. This formulation matched with low drift nozzles has resulted in $90 \%$ reduction in drift compared to a tank mix of 2,4-D DMA and glyphosate DMA [10]. This product will be introduced with crops tolerant to this formulation, allowing the product to be applied preplant or post plant in tolerant corn, soybean and cotton crops [11]. The label rate of this formulation in Canada will be $1720 \mathrm{~g} \cdot \mathrm{ae} \cdot \mathrm{ha}^{-1}$; $840 \mathrm{~g} \cdot \mathrm{ae} \cdot \mathrm{ha}^{-1}$ of 2,4-D choline and 880 $\mathrm{g} \cdot \mathrm{ae} \cdot \mathrm{ha}^{-1}$ of glyphosate DMA. The objectives of this research was to determine the biologically effective rate of 2,4-D amine, glyphosate DMA, 2,4-D amine plus glyphosate DMA and 2,4-D choline/glyphosate DMA for the control of glyphosate susceptible and glyphosate resistant Canada fleabane.

\section{Materials and Methods}

This experiment was completed twice over a two-year period (2012 and 2013) and included four Canada fleabane biotypes, two resistant to glyphosate (GR1 and GR2) and two susceptible to glyphosate (GS1 and GS2). Seeds were collected from various farms in southwestern Ontario. There were four replications in each run. All the biotypes were tested in 2011 to determine if they were susceptible or resistant to glyphosate [8]. Seeds of each biotype were planted in $25 \mathrm{~cm}$ by $25 \mathrm{~cm}$ trays filled with potting soil (Sunshine Professional Growing Mix containing peat moss, perlite, and dolomitic limestone). When the Canada fleabane seedlings were around 1-2 $\mathrm{cm}$ in diameter they were transplanted individually into pots that were $10 \mathrm{~cm}$ in diameter. The pots were placed in a greenhouse with a 16 hour photoperiod and a $25 / 18^{\circ} \mathrm{C}$ day/night temperature with a relative humidity of $50 \%$ to $60 \%$ and were watered with tap water every morning. Each biotype was treated with 10 rates of four different herbicides; 2,4-D amine, glyphosate DMA, a tank mix of 2,4-D amine and glyphosate DMA and 2,4-D choline/glyphosate DMA formulation. 2,4-D amine rates were 0, 26.2, 52.4, 104.8, 209.6, 419.3, 838.5, 1677, 3354, and $6708 \mathrm{~g} \cdot \mathrm{ae} \cdot \mathrm{ha}^{-1}$. Glyphosate rates were $0,27.5,55.1,110.2,220.4,440.8,881.5,1763,3526$, and 7052 $\mathrm{g} \cdot \mathrm{ae} \cdot \mathrm{ha}^{-1}$. The tank mix treatment were the 2,4-D amine and glyphosate rates applied together $(0,26.2+27.5$, $52.4+55.1,104.8+110.2,209.6+220.4,419.3+440.8,838.5+881.5,1677+1763,3354+3526,6708+$ $7052 \mathrm{~g} \cdot \mathrm{ae} \cdot \mathrm{ha}^{-1}$ ). The 2,4-D choline/glyphosate DMA rates were $0,53.8,107.5,215,430,860,1720,3440,6880$, 
$13,760 \mathrm{~g} \cdot \mathrm{ae} \cdot \mathrm{ha}^{-1}$.

Herbicides were applied in a stationary spray chamber when the Canada fleabane rosette was $10 \mathrm{~cm}$ in diameter. Herbicides were applied with a single 80-02 flat fan nozzle with the sprayer speed set at $2.15 \mathrm{~km} \cdot \mathrm{h}^{-1}$ at $280 \mathrm{kPa}$. The top of the weed canopy was set $45 \mathrm{~cm}$ below the nozzle. Control ratings were taken 1, 7, 14, 21, and 35 days after application (DAA). Shoot dry weight was determined at 35 DAA by cutting the living Canada fleabane plants at the soil line, drying them at $60 \mathrm{C}$ and then weighed.

Statistical analysis was completed using an analysis of variance with the SAS PROC MIXED procedure in SAS 9.1 (SAS Institute, Cary, NC). The control ratings were partitioned into fixed effects and random effects using the F-tests and Z-tests to determine significance, respectively. The fixed effects included the treatment and biotype and the treatment by biotype interaction. The random effects included the run, replication, treatment by run interaction and the biotype by run interaction. If there was not a significant run by treatment or biotype by treatment interaction then all factors were analyzed together. If there was a significant interaction between the treatment and run then the runs were analyzed separately and if there was significant biotype by treatment interaction then the biotypes were analyzed separately. Transformations were done if necessary to better meet the assumptions of normality (errors are random, homogeneous, independent of effects and normally distributed). A Type 1 error rate of 0.05 was used for all the statistical tests. The PROC NLIN procedure in SAS 9.1 was used to regress the data using the log-logistic equation [12]:

$$
Y=C+\frac{D-C}{1+\exp [b(\log (x)-\log (I 50))]}
$$

$Y$ is the percent control of Canada fleabane. $C$ is the lower limit. $D$ is the upper limit. $b$ is the slope of the line, and $\mathrm{I} 50$ is the rate where there was 50\% response between the upper and lower limit [12]. The I50 values, including the standard error were compared for the different treatments to determine if the curves were shifted from each other (either left or right), indicating treatment differences. For the dry weight data, a positive slope (b) was used while for the control ratings a negative slope was used $(-b)$. The ED 50, 80 and 95 values represent the rate that provides 50\%, 80\% and 95\% control of Canada fleabane. They were determined by using 50, 80 and 95 as the $Y$ value and solving for $\mathrm{x}$ representing the rate. For dry weight 50, 20 and 5 were used for the $Y$ values to determine the required rate.

\section{Results and Discussion}

\subsection{Biologically Effective rate of Glyphosate}

At 7 DAA, the glyphosate resistant (GR) and glyphosate susceptible (GS) biotypes responded differently to the glyphosate applied and were analyzed separately. The GR biotypes had very few to no symptoms, whereas the GS biotypes had yellowing of the growing point especially at the high rates of glyphosate. At 7 DAA, the upper limit $(D)$ values for the GR and GS biotypes were 29 and 69, respectively (Table 1). At 7 DAA, the highest rate of glyphosate (7052 g·ae·ha ${ }^{-1}$ ) did not provide 50\% control of the GR biotypes while a rate of $3466 \mathrm{~g} \cdot \mathrm{ae}^{\mathrm{h}} \mathrm{ha}{ }^{-1}$ provided 50\% control of the GS biotypes (Table 1). At 14 DAA, the highest rate of glyphosate still did not provide $50 \%$ control of the GR biotypes (Table 1). At 14 DAA, a glyphosate rate of 485 - 978 g.ae·ha ${ }^{-1}$ was required for $50 \%$ control of the GS biotypes (Table 1). At 14 DAA, the rate of glyphosate required to provide $95 \%$ control of the GS biotype was $2595 \mathrm{~g} \cdot \mathrm{ae} \cdot \mathrm{ha}^{-1}$ to greater than $7052 \mathrm{~g} \cdot \mathrm{ae} \cdot \mathrm{ha}^{-1}$ (Table 1). These data are in contrast

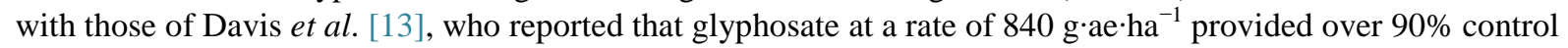
of GS Canada fleabane. At 21 DAA, glyphosate did not provide 50\% control of the GR biotypes while glyphosate at $584 \mathrm{~g} \cdot \mathrm{ae} \cdot \mathrm{ha}^{-1}$ provided 50\% control of the GS biotypes (Table 1). At 35 DAA, the upper limit (D) for the GR biotypes was 41, with this low D value the ED 50, 80 and 95 values could not be determined (Table 1). At 35 DAA, the rates of glyphosate required to provide 50\%, 80\% and 95\% control of the GS biotypes were 394 , 1156 and $3841 \mathrm{~g} \cdot \mathrm{ae} \cdot \mathrm{ha}^{-1}$, respectively (Table 1). At 35 DAA, the dry weight data were similar to the control ratings, the GR biotypes had a high C limit of 56.6 and the ED 50, 80 and 95 could not be determined. The rates of glyphosate that reduced the dry weight of the GS biotypes by 50\%, 80\% and 95\% were 591, 1196,3474 $\mathrm{g} \cdot \mathrm{ae} \cdot \mathrm{ha}^{-1}$, respectively (Table 1 ). The rates of glyphosate for the control of the GS biotype in this study were higher than those reported by Davis et al. [13] who found that glyphosate applied at $840 \mathrm{~g} \cdot \mathrm{ae}^{\circ} \mathrm{ha}^{-1} \mathrm{provided}^{90 \%}$ control. Byker et al. [8] sprayed these biotypes with glyphosate at $900 \mathrm{~g} \cdot \mathrm{ae} \cdot \mathrm{ha}^{-1}$ and they survived, while these 
Table 1. Rate response of glyphosate on the control of glyphosate susceptible and resistant Canada fleabane biotype 7, 14, 21, 35 DAA and the dry weight 35 DAA in a controlled environment in 2012 and 2013.

\begin{tabular}{cccccccccc}
\hline Rate Response & \multicolumn{1}{c}{ Biotype $^{\mathrm{v}}$} & Run & $\mathrm{D}^{\mathrm{z}}$ & $\mathrm{C}$ & $\mathrm{B}^{\mathrm{y}}$ & $\mathrm{I}_{50}^{\mathrm{x}}$ & $\mathrm{ED}_{50}^{\mathrm{w}}$ & $\mathrm{ED}_{80}$ & $\mathrm{ED}_{95}$ \\
\hline 7 DAA & GR1 and GR2 & R1 and R2 & $29(0)$ & $0.1(0.1)$ & $0.9(0.2)$ & $523(127)$ & - & - & - \\
& GS1 and GS2 & R1 and R2 & $69(13)$ & $0.3(3.3)$ & $0.8(0.2)$ & $999(564)$ & 3466 & - & - \\
14 DAA & GR1 and GR2 & R1 and R2 & $41(1)$ & $0.3(0.2)$ & $1.2(0.3)$ & $1349(390)$ & - & - & - \\
& GS1 and GS2 & R1 & $100(0)$ & $2.3(0.1)$ & $1.8(0.3)$ & $497(57)$ & 485 & 1071 & 2595 \\
& GS1 and GS2 & R2 & $100(0)$ & $3.5(3.0)$ & $1.1(0.1)$ & $1045(130)$ & 978 & 3538 & $>7052$ \\
21 DAA & GR1 and GR2 & R1 and R2 & $41(0)$ & $0.2(0.1)$ & $1.6(0.3)$ & $870(124)$ & - & - & - \\
& GS1 and GS2 & R1 and R2 & $99(0)$ & $2.0(0.1)$ & $1.2(0.2)$ & $597(86)$ & 584 & 1946 & $>7052$ \\
35 DAA & GR1 and GR2 & R1 and R2 & $41(0)$ & $0.0(0.2)$ & $1.5(0.3)$ & $915(165)$ & - & - & - \\
& GS1 and GS2 & R1 and R2 & $100(0)$ & $1.5(0.1)$ & $1.3(0.1)$ & $404(32)$ & 394 & 1156 & 3841 \\
Dry Weight & GR1 and GR2 & R1 and R2 & $92(2)$ & $56.6(5.8)$ & $4.4(3.2)$ & 3128 & - & - & - \\
& GS1 and GS2 & R1 and R2 & $93(3)$ & $0(0)$ & $1.3(0.2)$ & $366(44)$ & 591 & 1196 & 3474 \\
\hline
\end{tabular}

${ }^{\mathrm{z}} \mathrm{D}$ is the Upper limit and $\mathrm{C}$ is the lower limit; ${ }^{\mathrm{Y}} \mathrm{B}$ is the Slope of the line; ${ }^{\mathrm{X}} \mathrm{I} 50$ is where there is a $50 \%$ response; ${ }^{\mathrm{W}} \mathrm{ED}=$ the rate of glyphosate where there is 50, 80 and 95\% control of Canada fleabane; ${ }^{\mathrm{V}}$ Abbreviations: GR1 and GR2 are glyphosate resistant biotypes; GS1 and GS2 are glyphosate susceptible biotypes; DAA, days after application; R1 and R2 are the two runs of this experiment R1, 2012 and R2, 2013.

data indicate that these GR biotypes are highly resistant to glyphosate. Based on the dry weight at 35 DAA the resistance factor for the GR biotypes is 8.6.

\subsection{Biologically Effective Rate of 2,4-D Amine}

At 1 and 7 DAA, the control of both the GR and GS Canada fleabane biotypes with 2,4-D amine was similar and therefore the data were combined. At 1 and 7 DAA, the I50 values for 2,4-D amine were 5929 and 583, respectively (Table 2). The rates of 2,4-D amine required to provide 50\% control 1 and 7 DAA were 5929 and 3639 g.ae $\cdot \mathrm{ha}^{-1}$, respectively (Table 2). At 14 DAA, one of the GS biotypes could not be combined and was analyzed on its own. At 14 DAA, the I50 values were 53 and 91 and the rate of 2,4-D amine required to provide 50\% control was 115 - $195 \mathrm{~g} \cdot \mathrm{ae}^{-h^{-1}}$ (Table 2). The data for the control ratings 21 and 35 DAA and the dry weight data 35 DAA from the two runs could not be combined and were analyzed separately. The I50 values at 21 DAA were 59 and 267 and a 2,4-D amine rate of 60 - $323 \mathrm{~g} \cdot a \mathrm{ae} \cdot \mathrm{ha}^{-1}$ was required to provide $50 \%$ control (Table 2). Similar to these findings, Kruger et al. (2010b) had an I50 value of 199 - 314 at 28 DAA for 2,4-D ester. At 35 DAA, the I50 value was 51 and 179 and to achieve 50\% control of the Canada fleabane a rate of $51-179$ g.ae ha $^{-1}$ was required (Table 2). At 35 DAA, the rate of 2,4-D amine required to provide $95 \%$ control of the Canada fleabane was 259 - $4202 \mathrm{~g} \cdot \mathrm{ae}^{-} \mathrm{ha}^{-1}$ (Table 2). The I50 value for the dry weight analysis in this experiment was 64 and 457 for the two runs (Table 2). To achieve 50\% control of the Canada fleabane based on the dry weight data a rate of 86 - $948 \mathrm{~g} \cdot \mathrm{ae} \cdot \mathrm{ha}^{-1}$ of 2,4-D amine was needed (Table 2). To obtain 95\% control of Canada fleabane with 2,4-D amine according to the dry weight analysis there was a large difference between the two runs ranging from $240 \mathrm{~g} \cdot \mathrm{ae} \cdot \mathrm{ha}^{-1}$ to greater than $6780 \mathrm{~g} \cdot \mathrm{ae} \cdot \mathrm{ha}^{-1}$ (Table 2). Kruger et al. [14] reported that $560 \mathrm{~g} \cdot a \mathrm{a} \cdot \mathrm{ha}^{-1}$ of 2,4-D amine provided $90 \%$ control of $7 \mathrm{~cm}$ Canada fleabane which is in the range of these findings.

\subsection{Biologically Effective Rate of 2,4-D Amine plus Glyphosate}

For the biologically effective rate of the tank mix of 2,4-D amine and glyphosate, the control data at 1, 7, 14 and 21 DAA from all the biotypes could all be combined. The I50 values were 5464, 3475, 586 and 288 at 1, 7, 14, 21 DAA, respectively (Table 3). The rate of tank mix required to provide 50\% control 14 and 21 DAA was 717 g.ae $\cdot \mathrm{ha}^{-1}$ and $282 \mathrm{~g} \cdot \mathrm{ae} \cdot \mathrm{ha}^{-1}$, respectively (Table 3). At $21 \mathrm{DAA}$, the rate of tank mix required to provide 80 and 95\% control was 866 and $3641 \mathrm{~g} \cdot \mathrm{ae} \cdot \mathrm{ha}^{-1}$, respectively (Table 3). At 35 DAA, the data from the GS and GR biotypes were analyzed separately. The GR biotypes had a higher I50 value and required a higher rate of 2,4-D 
Table 2. Rate response of 2,4-D amine for the control glyphosate resistant and susceptible biotypes 1, 7, 14, 21, 35 DAA and the dry weight analysis conducted in a controlled experiment in 2012 and 2013.

\begin{tabular}{cccccccccc}
\hline Rate Response & \multicolumn{1}{c}{ Biotype $^{\mathrm{v}}$} & Run & $\mathrm{D}^{\mathrm{z}}$ & $\mathrm{C}$ & $\mathrm{B}^{\mathrm{y}}$ & $\mathrm{I}_{50}^{\mathrm{x}}$ & $\mathrm{ED}_{50}^{\mathrm{w}}$ & ED $_{80}$ & ED $_{95}$ \\
\hline 1 DAA & GR1, GR2, GS1, GS2 & R1 and R2 & $100(0)$ & $0(0)$ & $0.3(0.0)$ & $5929(877)$ & 5929 & $>6780$ & $>6780$ \\
7 DAA & GR1, GR2, GS1, GS2 & R1 and R2 & $68(10)$ & $0(0)$ & $0.6(0.1)$ & $583(348)$ & 3639 & - & - \\
14 DAA & GR1, GR2, GS2 & R1 and R2 & $78(0)$ & $0(0)$ & $0.8(0.1)$ & $91(17)$ & 195 & - & - \\
& GS1 & R1 and R2 & $67(4)$ & $0.2(7.9)$ & $1.4(0.6)$ & $53(17)$ & 115 & - & - \\
21 DAA & GR1, GR2, GS1, GS2 & R1 & $99(2)$ & $0.2(3.4)$ & $1.8(0.2)$ & $59(5)$ & 60 & 131 & 334 \\
& GR1, GR2, GS1, GS2 & R2 & $92(7)$ & $0(0)$ & $1.0(0.2)$ & $267(64)$ & 323 & 1967 & - \\
35 DAA & GR1, GR2, GS1, GS2 & R1 & $100(0)$ & $0.2(0.2)$ & $1.8(0.2)$ & $51(4)$ & 51 & 109 & 259 \\
& GR1, GR2, GS1, GS2 & R2 & $100(0)$ & $0.1(0.3)$ & $0.9(0.1)$ & $179(23)$ & 179 & 786 & 4202 \\
Dry Weight & GR1, GR2, GS1, GS2 & R1 & $97(4)$ & $0.1(2.1)$ & $2.3(0.4)$ & $64(6)$ & 86 & 129 & 240 \\
& GR1, GR2, GS1, GS2 & R2 & $97(7)$ & $0(0)$ & $0.9(0.2)$ & $457(124)$ & 948 & 2616 & $>6780$ \\
\hline
\end{tabular}

${ }^{\mathrm{z}} \mathrm{D}$ is the upper limit and $\mathrm{C}$ is the lower limit; ${ }^{\mathrm{y}} \mathrm{B}$ is the slope of the line; ${ }^{\mathrm{x}} \mathrm{I} 50$ is the rate where there is a $50 \%$ response; ${ }^{\mathrm{w}} \mathrm{ED}=\mathrm{the}$ rate of $2,4-\mathrm{D}$ amine where there is 50\%, $80 \%$ and 95\% control; ${ }^{v}$ Abbreviations: GR1 and GR2 are glyphosate resistant biotypes; GS1 and GS2 are glyphosate susceptible biotypes; DAA, days after application; R1 and R2 are the two runs of this experiment R1, 2012 and R2, 2013.

Table 3. Rate response of a tank mix of glyphosate plus 2,4-D amine for the control of glyphosate resistant and susceptible Canada fleabane biotypes 1, 7, 14, 21, 35 DAA and the dry weight data conducted in a controlled environment in 2012 and 2013.

\begin{tabular}{cccccccccc}
\hline Rate Response & \multicolumn{1}{c}{ Biotype $^{\mathrm{v}}$} & Run & $\mathrm{D}^{\mathrm{z}}$ & $\mathrm{C}$ & $\mathrm{B}^{\mathrm{y}}$ & $\mathrm{I}_{50}^{\mathrm{x}}$ & $\mathrm{ED}_{50}^{\mathrm{w}}$ & $\mathrm{ED}_{80}$ & $\mathrm{ED}_{95}$ \\
\hline 1 DAA & GR1, GR2, GS1, GS2 & R1 and R2 & $92(6)$ & $0(0)$ & $0.3(0)$ & $5463(9163)$ & 9736 & $>13760$ & - \\
7 DAA & GR1, GR2, GS1, GS2 & R1 and R2 & $92(19)$ & $0(0)$ & $0.5(0.1)$ & $3475(3133)$ & 4933 & $>13760$ & - \\
14 DAA & GR1, GR2, GS1, GS2 & R1 and R2 & $92(5)$ & $0(0)$ & $0.8(0.1)$ & $586(106)$ & 717 & 5490 & - \\
21 DAA & GR1, GR2, GS1, GS2 & R1 and R2 & $98(2)$ & $3.0(3.2)$ & $1.3(0.2)$ & $288(30)$ & 282 & 866 & 3641 \\
35 DAA & GR1 and GR2 & R1 and R2 & $100(0)$ & $1.0(0.2)$ & $1.3(0.2)$ & $267(27)$ & 263 & 768 & 2552 \\
& GS1 and GS2 & R1 and R2 & $100(0)$ & $6.8(3.3)$ & $2.0(0.2)$ & $181(14)$ & 168 & 347 & 761 \\
\multirow{2}{*}{ Dry Weight } & GR1 and GR2 & R1 and R2 & $85(4)$ & $1.9(3.2)$ & $2.5(0.6)$ & $442(49)$ & 551 & 813 & 1635 \\
& GS1 & R1 and R2 & $99(6)$ & $0(0)$ & $0.9(0.2)$ & $86(21)$ & 181 & 499 & 2305 \\
& GS2 & R1 and R2 & $87(4)$ & $0(0)$ & $3.3(0.7)$ & $230(17)$ & 273 & 361 & 552 \\
\hline
\end{tabular}

${ }^{\mathrm{z}} \mathrm{D}$ is the upper limit and $\mathrm{C}$ is the lower limit; ${ }^{\mathrm{y}} \mathrm{B}$ is the slope of the line; ${ }^{\mathrm{x}} \mathrm{I} 50$ is the rate where there is a $50 \%$ response; ${ }^{\mathrm{w}} \mathrm{ED}=\mathrm{the}$ rate of the tank mix of glyphosate and 2,4-D amine where there is 50\%, 80\% and 95\% control; ${ }^{\mathrm{v}}$ Abbreviations: GR1 and GR2 are glyphosate resistant biotypes; GS1 and GS2 are glyphosate susceptible biotypes; DAA, days after application; R1 and R2 are the two runs of this experiment R1, 2012 and R2, 2013.

amine plus glyphosate to achieve 50\%, 80\% and 95\% control. The rate of the tank mix required to provide $95 \%$

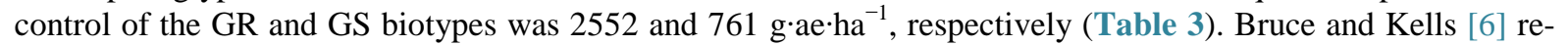
ported that an early preplant application of $210 \mathrm{~g} \cdot \mathrm{ae}^{\mathrm{h}} \mathrm{ha}^{-1}$ of glyphosate plus $560 \mathrm{~g} \cdot \mathrm{ae}^{\mathrm{h}} \mathrm{ha}^{-1}$ of 2,4-D amine provided $99 \%$ control of Canada fleabane, which is a total of $730 \mathrm{~g} \cdot \mathrm{ae} \cdot \mathrm{ha}^{-1}$ of tank mix similar to the rate that was required in this experiment, however Bruce and Kells [6] did use a higher percentage of 2,4-D in their tank mix. For the dry weight data analysis the GR and GS biotypes were analyzed separately and the data from the two GS biotypes could not be combined either. To achieve 95\% reduction in Canada fleabane dry weight of the GR biotypes a tank mix rate of $1635 \mathrm{~g} \cdot \mathrm{ae} \cdot \mathrm{ha}^{-1}$ was necessary (Table 3). The GS biotypes needed a rate between 552 $2304 \mathrm{~g} \cdot \mathrm{ae} \cdot \mathrm{ha}^{-1}$ to reduce Canada fleabane dry weight by 95\% (Table 3). The amount of 2,4-D amine in the tank mix is $48 \%$ and therefore the rates to achieve $50 \%$ and $95 \%$ control of the Canada fleabane are equivalent or improved from the rates of 2,4-D amine applied alone showing that the glyphosate and 2,4-D do not antagonize each other when they are mixed together.

\subsection{Biologically Effective Rate of 2,4-D Choline/Glyphosate}

At 1 and 7 DAA, 2,4-D choline/glyphosate DMA provided equivalent control of the GR and GS biotypes and 
the data could be combined. At 1 DAA, the symptoms included severe twisting and yellowing of the growing point with the higher rates and slight bending of the leaf tips at the lower rates. At 1 DAA, a rate greater than $13,760 \mathrm{~g} \cdot \mathrm{ae} \cdot \mathrm{ha}^{-1}$ was required to provide $50 \%, 80 \%$ or $95 \%$ Canada fleabane control (Table 4). At 7 DAA, to achieve $50 \%$ control of Canada fleabane a rate of $3450 \mathrm{~g} \cdot \mathrm{ae} \cdot \mathrm{ha}^{-1}$ was needed, while a rate greater than 13,760 g.ae $\cdot \mathrm{ha}^{-1}$ was needed to provide $80 \%$ and $95 \%$ control (Table 4). At 14 DAA, the data from the GR and GS biotypes could not be combined and were analyzed separately. The rate required to provide $50 \%$ control of the

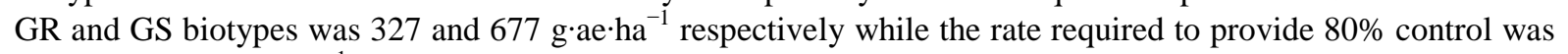
2140 and 3697 gae $\cdot \mathrm{ha}^{-1}$, respectively (Table 4). At 21 and 35 DAA and for the dry weight data, the GR and GS biotypes were still analyzed separately and the two runs for the GR biotypes were also separated. For the GS biotypes 21, 35 DAA and the dry weight data had I50 values of 109, 85, and 85, respectively (Table 4). To achieve 50\%, 80\% and 95\% control of the GS biotypes 21 DAA a rate of $111 \mathrm{~g} \cdot \mathrm{ae} \cdot \mathrm{ha}^{-1}$, $353 \mathrm{~g} \cdot \mathrm{ae} \cdot \mathrm{ha}^{-1}$ and 1418 $\mathrm{g} \cdot \mathrm{ae} \cdot \mathrm{ha}^{-1}$ was required, respectively (Table 4). At 35 DAA, a rate of $85 \mathrm{~g} \cdot \mathrm{ae} \cdot \mathrm{ha}^{-1}, 187 \mathrm{~g} \cdot \mathrm{ae} \cdot \mathrm{ha}^{-1}$ and 454 $\mathrm{g} \cdot \mathrm{ae} \cdot \mathrm{ha}^{-1}$ was needed to provide $50 \%, 80 \%$ and $95 \%$ control of the GS biotypes, respectively (Table 4). The dry weight analysis of the GS biotypes found that a slightly higher rate of 2,4-D choline/glyphosate DMA was re-

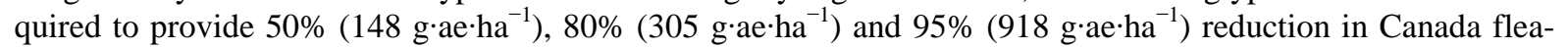
bane biomass compared to the ratings taken 35 DAA (Table 4). The I50 values for the GR Canada fleabane biotypes 21, 35 DAA and the dry weight data in the first run were 99, 68 and 128 and in the second run were 422, 264, and 531, respectively (Table 4). The GR biotypes in the second run required a higher rate of 2,4-D choline/glyphosate DMA to provide $50 \%, 80 \%$ and $95 \%$ control of the Canada fleabane compared to the GR biotypes in the first run. At 21 DAA, the GR plants in the first run required $99 \mathrm{~g} \cdot \mathrm{ae}^{-\mathrm{ha}^{-1}}, 232 \mathrm{~g} \cdot \mathrm{ae} \cdot \mathrm{ha}^{-1}$ and 608 $\mathrm{g} \cdot \mathrm{ae} \cdot \mathrm{ha}^{-1}$ of the formulation while in the second run required rates of $436 \mathrm{~g} \cdot \mathrm{ae} \cdot \mathrm{ha} \mathrm{a}^{-1}, 1894 \mathrm{~g} \cdot \mathrm{ae} \cdot \mathrm{ha}^{-1}$ and 12,435 g.ae $\cdot h a^{-1}$ to provide $50 \%, 80 \%$ and $95 \%$ control, respectively (Table 4). Similarly, dry weight reductions of the GR biotypes in the second run needed $875 \mathrm{~g} \cdot \mathrm{ae} \cdot \mathrm{ha}^{-1}, 1752 \mathrm{~g} \cdot \mathrm{ae} \cdot \mathrm{ha}{ }^{-1}$ and $5008 \mathrm{~g} \cdot \mathrm{ae} \cdot \mathrm{ha}^{-1}$ to achieve $50 \%, 80 \%$ and $95 \%$ biomass reductions, which were greater than those in the first run $150 \mathrm{~g} \cdot \mathrm{ae} \cdot \mathrm{ha}^{-1}$, $189 \mathrm{~g} \cdot \mathrm{ae} \cdot \mathrm{ha}^{-1} \mathrm{and}^{-168}$ g.ae $h a^{-1}$, respectively (Table 4). The label rate of 2,4-D choline/glyphosate DMA of 1720 gaae $\cdot \mathrm{ha}^{-1}$ provided over $95 \%$ control of the GS biotypes but this label rate did not consistently provide over $95 \%$ of the GR biotypes.

Overall, the tank mix of 2,4-D amine plus glyphosate and the 2,4-D choline/glyphosate DMA formulation provide similar control of the GR and GS Canada fleabane biotypes. At 7 DAA, the rate required to provide $50 \%$ control was less with the 2,4-D choline/glyphosate DMA formulation (3450 g·ae $\cdot \mathrm{ha}^{-1}$ ) than the tank mix of

Table 4. Controlled environment experiments conducted in 2012 and 2013 examining the rate response of 2,4-D choline/ glyphosate DMA on the control of glyphosate resistant and susceptible Canada fleabane 1, 7, 14, 21, 35 DAA and the dry weight analysis.

\begin{tabular}{|c|c|c|c|c|c|c|c|c|c|}
\hline Rate Response & Biotype $^{v}$ & Run & $\mathrm{D}^{\mathrm{z}}$ & C & $\mathrm{B}^{\mathrm{y}}$ & $I_{50}^{x}$ & $\mathrm{ED}_{50}^{\mathrm{w}}$ & $\mathrm{ED}_{80}$ & $\mathrm{ED}_{95}$ \\
\hline $1 \mathrm{DAA}$ & GR1, GR2, GS1, GS2 & $\mathrm{R} 1$ and $\mathrm{R} 2$ & $100(0)$ & $0.4(1.4)$ & $0.4(0)$ & 37833 (5883) & $>13760$ & $>13760$ & $>13760$ \\
\hline 7 DAA & GR1, GR2, GS1, GS2 & $\mathrm{R} 1$ and $\mathrm{R} 2$ & $100(0)$ & $0.1(2.5)$ & $0.5(0)$ & 3471 (520) & 3450 & $>13760$ & $>13760$ \\
\hline \multirow[t]{2}{*}{14 DAA } & GS1 and GS2 & $\mathrm{R} 1$ and R2 & $92(5)$ & $0(0)$ & $0.9(0.1)$ & $271(51)$ & 327 & 2140 & - \\
\hline & GR1 and GR2 & $\mathrm{R} 1$ and $\mathrm{R} 2$ & $100(0)$ & $0(0)$ & $0.6(0)$ & 677 (88) & 677 & 6397 & $>13760$ \\
\hline \multirow[t]{3}{*}{$21 \mathrm{DAA}$} & GS1 and GS2 & $\mathrm{R} 1$ and R2 & 99 (3) & $0(0)$ & $1.2(0.2)$ & 109 (14) & 111 & 353 & 1418 \\
\hline & GR1 and GR2 & $\mathrm{R} 1$ & $100(0)$ & $0.3(0.3)$ & $1.6(0.2)$ & $99(8)$ & 99 & 232 & 608 \\
\hline & GR1 and GR2 & $\mathrm{R} 2$ & $99(1)$ & $0(0.9)$ & $1.0(0.2)$ & $422(120)$ & 436 & 1894 & 12435 \\
\hline \multirow[t]{3}{*}{35 DAA } & GS1 and GS2 & $\mathrm{R} 1$ and R2 & $100(2)$ & $0(0)$ & $1.8(0.2)$ & $85(5)$ & 85 & 187 & 454 \\
\hline & GR1 and GR2 & $\mathrm{R} 1$ & $100(0)$ & $0.1(0)$ & $1.7(0.3)$ & $68(7)$ & 68 & 151 & 373 \\
\hline & GR1 and GR2 & $\mathrm{R} 2$ & $100(0)$ & $0.2(0.4)$ & $1.3(0.1)$ & 264 (31) & 263 & 793 & 2737 \\
\hline \multirow[t]{3}{*}{ Dry Weight } & GS1 and GS2 & $\mathrm{R} 1$ and R2 & $100(0)$ & $0(0)$ & $1.3(0.2)$ & $85(10)$ & 148 & 305 & 918 \\
\hline & GR1 and GR2 & $\mathrm{R} 1$ & $93(3)$ & $0(0)$ & $3.9(0.7)$ & $128(7)$ & 150 & 189 & 268 \\
\hline & GR1 and GR2 & $\mathrm{R} 2$ & $97(1)$ & $0(0)$ & $1.3(0.3)$ & $531(115)$ & 875 & 1752 & 5008 \\
\hline
\end{tabular}

${ }^{\mathrm{z}} \mathrm{D}$ is the upper limit and $\mathrm{C}$ is the lower limit; ${ }^{\mathrm{y}} \mathrm{B}$ is the slope of the line; ${ }^{\mathrm{x}} \mathrm{I} 50$ is the rate where there is a $50 \%$ response; ${ }^{\mathrm{w}} \mathrm{ED}=\mathrm{the}$ rate of $2,4-\mathrm{D}$ choline/glyphosate DMA where there is 50\%, 80\% and 95\% control of Canada fleabane; ${ }^{\mathrm{v}}$ Abbreviations: GR1 and GR2 are glyphosate resistant biotypes; GS1 and GS2 are glyphosate susceptible biotypes; DAA, days after application; R1 and R2 are the two runs of this experiment R1, 2012 and R2, 2013. 
2,4-D amine plus glyphosate (4933 g.ae $\cdot \mathrm{ha}^{-1}$ ) (Table 3 and Table 4). This same trend was observed at 14 DAA, when the rate required to provide $50 \%$ control with the 2,4-D choline/glyphosate DMA formulation was 327 $677 \mathrm{~g} \cdot \mathrm{ae} \cdot \mathrm{ha}^{-1}$ and the rate for the tank mix of 2,4-D amine plus glyphosate was $717 \mathrm{~g} \cdot \mathrm{ae} \cdot \mathrm{ha}^{-1}$ (Table 4). At 35 DAA, for both the 2,4-D choline/glyphosate DMA application and the tank mix of 2,4-D amine and glyphosate the GS and GR Canada fleabane biotypes could not be combined. When just comparing the GS biotypes 35 DAA a lower rate of 2,4-D choline/glyphosate DMA was required $\left(85,187\right.$, and $\left.454 \mathrm{~g} \cdot a \cdot \cdot \mathrm{ha}^{-1}\right)$ to provide $50 \%$, $80 \%$ and $95 \%$ control compared to the GS plants receiving the tank mix application of 2,4-D amine and glyphosate (168, 347 and 761 gae.ha ${ }^{-1}$ ) (Table 3 and Table 4). For the dry weight analysis the GS biotypes required a lower rate of 2,4-D choline/glyphosate DMA at $148 \mathrm{~g} \cdot \mathrm{ae} \cdot \mathrm{ha}^{-1}$ and $305 \mathrm{~g} \cdot \mathrm{ae} \cdot \mathrm{ha}^{-1}$ to provide 50 and $80 \%$ reduction in biomass compared to the tank mix application that required $181-273 \mathrm{~g} \cdot \mathrm{ae}^{\mathrm{h}} \mathrm{ha}^{-1}$ and $361-499$ g.ae $\cdot \mathrm{ha}^{-1}$ to provide 50 and 80\% control, respectively (Table 3 and Table 4). There was little difference found between the tank mix and the 2,4-D choline/glyphosate DMA premix formulation applied to the GR Canada fleabane biotypes at 21 and 35 DAA or in the dry weight ratings.

\section{Conclusion}

In summary, there was no difference between the tank mix of 2,4-D amine and glyphosate DMA to the 2,4-D choline/glyphosate DMA formulation by 35 DAA on the GR biotypes. The GS plants were more sensitive to the 2,4-D choline/glyphosate DMA formulation compared to the tank mix of 2,4-D amine plus glyphosate at 35 DAA and in the dry weight analysis. Kruger et al. [14] reported that some Canada fleabane biotypes might respond differently to the various salt formulations of 2,4-D and this might explain the difference between the GS and GR biotypes with the choline and amine formulations. At the early evaluation timings 7 and 14 DAA, the 2,4-D choline/glyphosate DMA was more efficacious than the tank mix of 2,4-D amine and glyphosate DMA on both the GS and GR biotypes.

\section{Acknowledgements}

Funding for this project was provided in part by the Grain Farmers of Ontario and the GF2 program of the Agricultural Adaptation Council.

\section{References}

[1] Holm, L., Doll, J., Holm, E., Pancho, J.V. and Herberger, J.P. (1997) World Weeds: Natural Histories and Distributions. J. Wiley, New York, 226-235.

[2] Kruger, G.R., Davis, V.M., Weller S.C. and Johnson W.G. (2010) Growth and Seed Production of Horseweed (Conyza canadensis) Populations after Exposure to Postemergence 2,4-D. Weed Science, 58, 413-419. http://dx.doi.org/10.1614/WS-D-10-00022.1

[3] Nandula, V.K., Eubank, T.W., Poston, D.H., Koger, C.H. and Reddy K.N. (2006) Factors Affecting Germination of Horseweed (Conyza canadensis). Weed Science, 54, 898-902. http://dx.doi.org/10.1614/WS-06-006R2.1

[4] Weaver, S.E. (2001) The biology of Canadian weeds. 115. Conyza canadensis. Canadian Journal of Plant Science, 81, 867-875. http://dx.doi.org/10.4141/P00-196

[5] Dauer, J.T., Mortensen, D.A. and Van Gessel, M.J. (2007) Temporal and Spatial Dynamics of Long-Distance Conyza canadensis Seed Dispersal. Journal of Applied Ecology, 44, 105-114. http://dx.doi.org/10.1111/j.1365-2664.2006.01256.x

[6] Bruce, J.A. and Kells, J.J. (1990) Horseweed (Conyza canadensis) Control in No-Tillage soybeans (Glycine max) with Preplant and Preemergence Herbicides. Weed Technology, 4, 642-647.

[7] Heap, I. (2014) The International Survey of Herbicide Resistant Weeds. www.weedscience.com

[8] Byker, H.P., Soltani, N., Robinson, D., Tardif, F., Lawton, M. and Sikkema, P.H. (2013) Occurrence of Glyphosate and Cloransulam Resistant Canada Fleabane (Conyza canadensis L. Cronq.) in Ontario. Canadian Journal of Plant Science, 93, 851-855. http://dx.doi.org/10.4141/cjps2013-039

[9] Beckie, H.J. and Rebound, X. (2009) Selecting for Weed Resistance: Herbicide Rotation and Mixture. Weed Technology, 23, 363-370. http://dx.doi.org/10.1614/WT-09-008.1

[10] Hillger, D.E., Qin, K., Simpson, D.M. and Havens, P. (2012) Reduction in Drift and Volatility of Enlist ${ }^{\mathrm{TM}}$ Duo with Colex-D. Proceedings of the 65th Annual Meeting of the North Central Weed Science Society Conference Proceedings, 65, 38. 
[11] Anonymous (2012) Enlist Weed Control System News Release. Dow Agro Sciences publication, Weed Science Society of America, Indianapolis.

[12] Bowley, S. (2008) A Hitchhiker's Guide to Statistics in Plant Biology. 2nd Edition, Any Old Subject Books, Guelph, $266 \mathrm{p}$.

[13] Davis, V.M. Kruger, G.R. Stachler, J.M., Loux, M.M. and Johnson, W.G. (2009) Growth and Seed Production of Horseweed (Conyza canadensis) Populations Resistant to Glyphosate, ALS-Inhibiting and Multiple (Glyphosate + ALS-Inhibiting) Herbicides. Weed Science, 57, 494-504. http://dx.doi.org/10.1614/WS-09-024.1

[14] Kruger, G.R., Davis, V.M., Weller S.C. and Johnson, W.G. (2010) Control of Horseweed (Conyza canadensis) with Growth Regulator Herbicides. Weed Technology, 24, 425-429. http://dx.doi.org/10.1614/WT-D-10-00022.1 
Scientific Research Publishing (SCIRP) is one of the largest Open Access journal publishers. It is currently publishing more than 200 open access, online, peer-reviewed journals covering a wide range of academic disciplines. SCIRP serves the worldwide academic communities and contributes to the progress and application of science with its publication.

Other selected journals from SCIRP are listed as below. Submit your manuscript to us via either submit@scirp.org or Online Submission Portal.
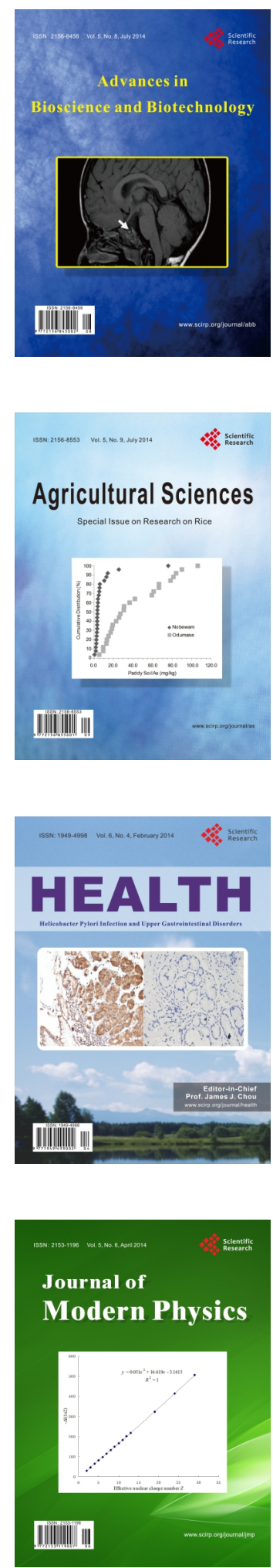
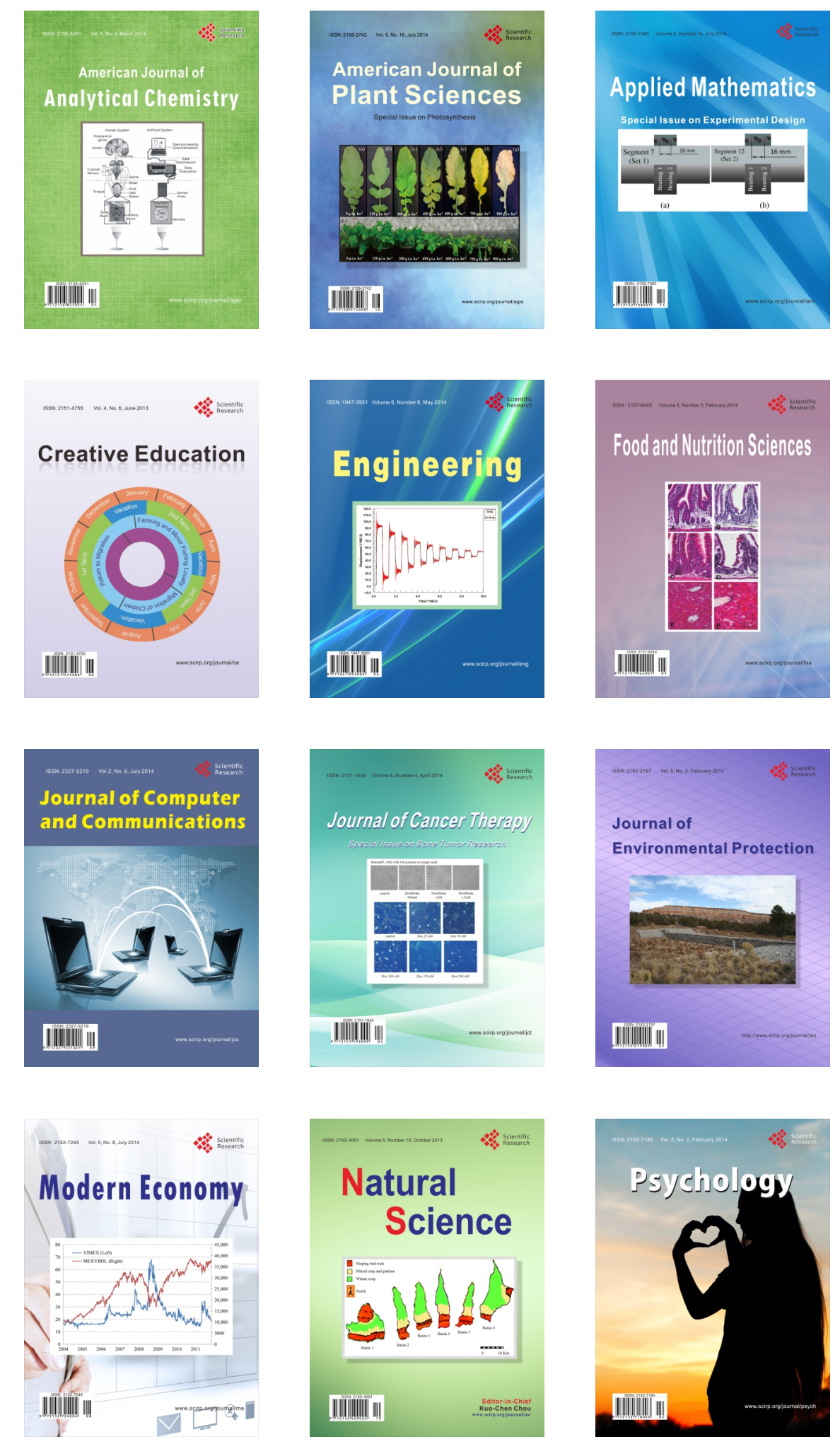